\title{
Strategies for accessing volume markets in the beef industry: A review of three cooperative business models
}

\author{
Nick McCann ${ }^{\mathrm{a}}$ and Frank Montabon, ${ }^{\mathrm{a}, *}$ Iowa State University
}

Submitted 14 October 2010 / Revised 17 February 2011 and 22 November 2011 / Accepted 16 December 2011 /

Published online 29 March 2012

Citation: McCann, N., \& Montabon, F. (2012). Strategies for accessing volume markets in the beef industry: A review

of three cooperative business models. Journal of Agriculture, Food Systems, and Community Development, 2(2), 37-49.

http://dx.doi.org/10.5304/jafscd.2012.022.014

Copyright (C) 2012 by New Leaf Associates, Inc.

\begin{abstract}
Given the increasing consolidation in the U.S. meat industry, smaller and specialty producers often have difficulty breaking into the market in profitable volumes. This paper examines three cooperative models for specialty beef producers. We offer a realistic examination of the potential for success of each model. Based on this, we identify the key attributes for a new model and offer guidance for future research efforts.
\end{abstract}

\section{Keywords}

beef producers, small-scale producers, specialty producers, market models

\section{Introduction}

In the U.S., consolidation in the meat industry has increased at a rapid pace. The number of major slaughter plants has declined rapidly. In 1997, the top four firms accounted for $40.6 \%$ of poultry

a Department of Supply Chain and Information Systems, 2340 Gerdin Business Building, Iowa State University, Ames, Iowa 50011 USA

* Corresponding author: Frank Montabon, +1-515-294-1208; montabon@iastate.edu slaughter and processing (Ollinger, Nguyen, Blayney, Chambers, \& Nelson, 2005). In $2004^{1}$ the top four firms accounted for approximately $64 \%$ of hog processing, and $80 \%$ of steer $\&$ heifer processing (U.S. Department of Agriculture, 2005). Today, the beef processing industry is classified by the Department of Justice (DOJ) as highly concentrated. ${ }^{2}$ This high concentration is further exemplified by a 2008 DOJ lawsuit to block the acquisition of National Beef Packing by JBS SA on antitrust grounds (Zippay, 2008).

With this consolidation of the meat processing industry, there has also been a strong move toward the practice of supply chains which are defined by Barkema, Drabenstott, and Novack as "tightly

\footnotetext{
${ }^{1}$ Note that these were most recent years for which we could find USDA data.

2 The DOJ defines "highly concentrated" as having a Herfendahl Hirschman Index (HHI) of higher than 1,800 (U.S. Department of Justice, 2009). The HHI is calculated by squaring the market share of competing firms and then summing the resulting numbers. According to a 2008 study by the Agricultural and Applied Economics Association, the beef industry has an HHI of 1,826 when looking at federally inspected slaughter data (Anderson \& Hudson, 2008).
} 
orchestrated production, processing, and marketing arrangements stretching from genetics to grocery" (2001, p. 36). The first meat industry to incorporate supply chain methods was poultry, which led to a surge in its share of the meat market with its market share gains coming from beef. Following the poultry industry's lead, the pork industry also began to incorporate supply chain strategies into its processes (Barkema et al., 2001). The beef industry, with its longer supply chain and traditionally more independent producers, has lagged behind both the pork and poultry industries in its supply chain integration.

Consolidation and coordination of the meat supply chain has in many ways been beneficial to the meat industry. However, small producers have not always benefited from these changes. The food industry has seen consolidation, integration, and coordination in the pursuit of economies of scale and scope, and lower transaction costs. Increased processor consolidation and the resulting market power effects have caused distributional income losses to all food producers (Sexton, 2000).

One option for small beef producers in response to the drive for consolidation and coordination is to form cooperatives to achieve effective scale and market power. In this paper we present three cooperative models, with the goal of creating a new model for small producers seeking to access volume markets. We also examine the attributes of each model.

\section{Methodology}

The case studies include three beef cooperatives that have pursued very different strategies that allow small beef producers to access volume beef markets. Of these three cooperatives, two are currently successful and one is no longer in business. Comments by Dick Bradbury, founding member of Country Natural Beef, and Mike Lorentz, owner of Lorentz Meats, are used to illustrate some of the concepts discussed.

The following attributes are used to analyze each case study. We define them here, use them during the discussion of each case study, and then review them in the discussion section to glean how the attributes form successful models.

Marketing Management Expertise: The ability of smaller producers to access volume markets clearly depends on the marketing expertise of the producers. This factor is of such importance that the Leopold Center at Iowa State University has created a specific stream of research, the Marketing and Food Systems Initiative (Leopold Center, n.d.), to investigate this issue.

Value System Coordination: In any supply chain, the ability of the supply chain partners to communicate and coordinate with each other is critical to superior chain performance. This has been specifically studied in the food industry (Stank, Crum, \& Arango, 1999). In general, chain coordination and how to achieve it have been popular topics in research. For just a few examples of this research, see Cousins, Handfield, Lawson, and Petersen (2006) and Holweg and Pil (2008). Weaver (2008) specifically argues that "collaboration across enterprises" is a key for successful value networks.

Scale: Maintaining the proper scale is a challenge for the smaller producer, as it must produce enough to interest buyers, but must to balance this against having enough capital (Born, 2001).

Valued-Added Traits: One way for small producers to differentiate themselves in a commodity market is to offer value-added traits such as organic production. (See Lau, Beverly, Kelley, \& Hanagriff (2007) for a discussion.) Some producers and cooperatives strive to create a "story" for consumers based on value-added traits. Dimra and Skuras (2003) discussed how "cues" such as certification and geographic association signal characteristics and properties of the product. Franks (2003) discusses the idea of "telling the organic story" to consumers. The literature thus clearly indicates that offering value-added traits may drive consumer interest.

Production System: The signal used to start production is a key differentiator in production system design. The usual classifications for these signals 
are "push" and "pull." The former refers to a system that produces based on a forecast and ends up pushing inventory down the chain. The latter system produces when a customer order is received (Krajewski \& Ritzman, 2002). Weaver (2008) argues that "push innovation" is being supplanted by "pull innovation," and uses the food industry as an illustration. He also notes the importance of collaboration to pull innovation and that pull innovation has been specifically used in the case of organic foods. This implies that of the attributes described, the more of them in place, the greater the chance for success.

Relationship with the End Customer: The final attribute considered is the cooperative's relationship with the end customer. The discussion of the attributes of production system and value system coordination indicates that the cooperative needs to have a good understanding of its customer base. Nitschke and O'Keefe (1997) specifically mention the importance of "establishing and maintaining direct relationships with key customers" in their study of Australian grain farmers. This was seen as a way to provide market signals back to the producers. Our literature review indicated that there has been relatively little research interest in the issue of agriculture cooperatives' efforts with regard to customer relationships, despite the rather voluminous research literature on relationship marketing and customer relationship management (see Das (2009) and Kim and Kim (2009) respectively for extensive literature reviews of these concepts).

\section{From Commodity to Integrated Value System: U.S. Premium Beef Ltd.}

U.S. Premium Beef Ltd. (USPB) is a closed, member-owned cooperative and is "designed to operate in the highly competitive, and fragmented, global agribusiness industry" (Katz \& Boland, 2000, p. 711). A closed, member-owned cooperative is defined by van Bekkum (2001) as a cooperative in which new entry is subject to the purchase of member rights. This is opposed to an open or collective cooperative structure, where entry is free. USPB was formed in 1996 as a reaction to two major difficulties in the beef market for cattle pro- ducers. First, the integrated poultry industry began to gain market share in the meat industry, mainly at the expense of beef. Additionally, there were large influxes of foreign beef into the U.S. domestic market, which was causing downward pressure on pricing.

One major problem identified by the cooperative founders was that, depending on market circumstances, each stage in the value system was put under stress, while another member in the value system was reaping the benefits. For example, when beef prices increased, feedlot owners benefited because they were marketing finished animals (Katz \& Boland, 2000). On the other hand, as beef prices decreased, the slaughter plants reaped the benefits, as producers were forced to sell at low prices.

The term "value system" comes from Michael Porter's value chain concept, where inputs pass through stages in a firm's production process to create a new value-added product. The value system is defined by Porter as an interconnected system of value chains (Porter 1985). For the beef industry, the value system would include the seed stock, cow calf, back-grounding (a system where weaned calves are grazed before being sent to the feedlot), feedlot, slaughter, processing, and retail segments.

Taking its cue from the pork and poultry industries, USPB sought to develop a system that increased coordination and communication throughout the value system. Unlike the pork and poultry industries, it wanted to create a system where risks and rewards were shared more equitably at each stage. This process was accomplished through several actions. First, it incorporated each stage of the cattle production process into the cooperative. Therefore, each stage of the value system was included in the membership. Producers are required to buy a share for each head of cattle they have in the system. Shares for one member can range from 100 to 100,000 (Katz \& Boland, 2000). However, regardless of the number of shares, there is only one vote per member in the cooperative. Feedlot owners with 100,000 head of 
cattle in the program do not have more voting power than a small cow calf producer with 100 head in the program.

Acquiring processing facilities is a major part of USPB's strategy for sharing risk and reward more equitably through the value system. USPB management knew that building a large slaughter and processing plant would not be viable, due to high fixed costs and investment. Instead, they chose to partner with a large slaughterhouse owned by Farmland National, which was a producercooperative-owned enterprise (a cooperative owned by actual cattle producers). This was attractive because it meant that the Farmland system was already familiar with dealing with cooperatives. As part of its partnership, USPB required an equity ownership interest in Farmland in order to maintain control over its ideas and to protect its shareholders. This was attractive to Farmland as they were operating with excess capacity. At the start, USPB had the ability to make annual delivery commitments of 835,000 head of cattle for processing (Katz \& Boland, 2000).

Processors often grade cattle carcasses on a grid to quantify carcass quality. The grid is determined by USPB management. ${ }^{3}$ Producers are able to earn "grid premiums" if their carcasses achieve characteristics considered higher quality. One advantage that USPB has been able to incorporate through its structures is providing feedback on carcass quality to producers. In a nonvertically integrated system, producers are often not informed of the shortcomings of their cattle. In an effort to market higher quality beef, USPB has been able to inform producers why their cattle are not able to receive grid premiums. This has helped producers better understand the needs of the market and adopt management practices to better deliver those products - and in the process to collect grid premiums.

USPB is an example of successfully integrating a value system that is more complicated (i.e., that has

${ }^{3}$ For a description of the grading process, see the USPB website: http://www.uspremiumbeef.com/FAQ.aspx more stages and less consolidation of producers) than both the poultry and pork industries. USPB was able to attain significant scale and shows how smaller producers can partner with larger feedlot and slaughter systems to create a value chain that allows them increased control and participation in the value system.

The key attributes for this model are a mix of proper scale and system coordination. These are exemplified by USPB deciding to partner with Farmland National and incorporating each stage of the cattle production process into the cooperative. To a lesser extent, it focused on value-added traits like U.S.-raised, and there was little push to develop direct relationships or contact with consumers.

We should note that USPB converted to a limited liability company (LLC) in 2004. There are two share classes. "A" shares "carry delivery rights and obligations like USPB shares did under the cooperative structure" (USPB, 2011a, para. 10) and "B" shares are for investors and have no delivery rights. The " $\mathrm{A}$ " shares thus look much like the previous cooperative structure. In fact, USPB describes itself as producer-owned (USPB, 2011b).

In 2008, USPB paid record cash distributions (USPB, 2009). This is in contrast to Farmland National's continued struggle with beef packing industry overcapacity and struggles to attain profitability (Anderson \& Hudson, 2008). Moody's downgraded Farmland National's credit rating in 2008 due to processing industry losses in 2007 and 2008. This performance comparison is further highlighted by USPB's blocked attempt to sell Farmland National to JBS Swift \& Co. in 2008 (Wilke \& Etter, 2008).

Figure 1 illustrates USPB's pursuit of value system coordination and scale to successfully provide access to volume markets for small producers. Notice that pull production systems and end consumer relationships are not included in this illustration. Additionally, value-added traits are included only to a lesser degree. 
Figure 1. U.S. Premium Beef Model

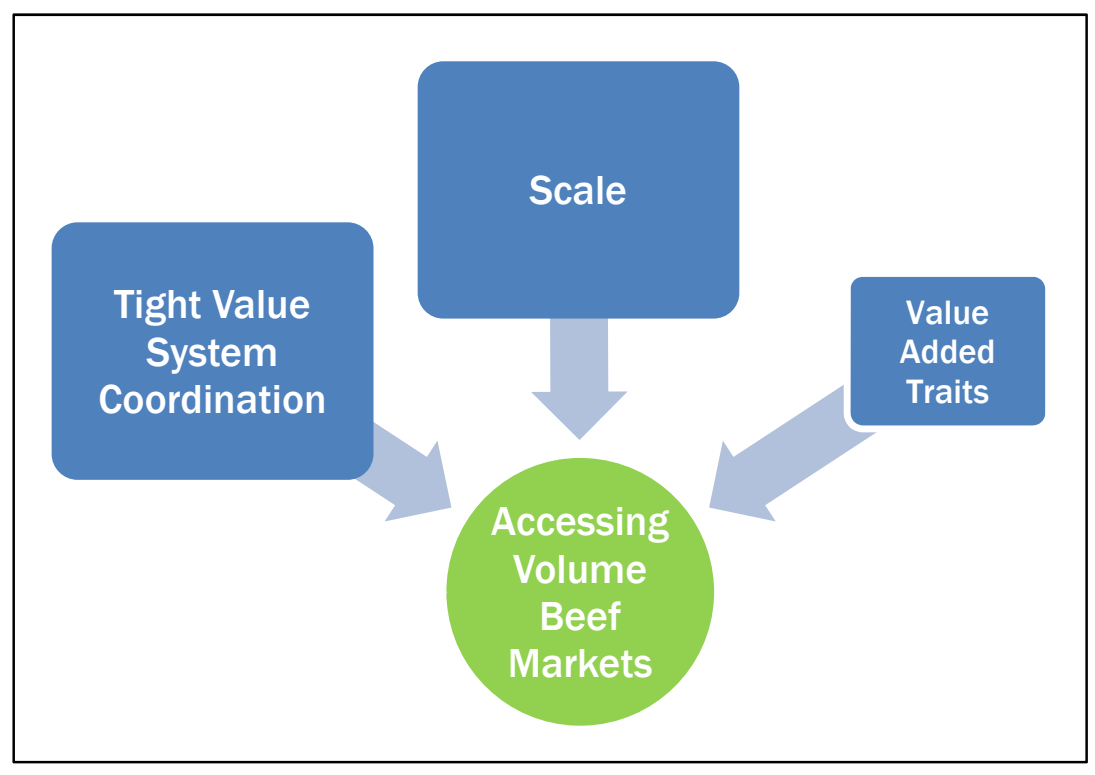

Tallgrass desperately needed a distributor or retailer that could buy in volume. However, due to the seasonal nature of its grass finishing process, there was no way to guarantee a steady supply of beef through the winter. The issue of supply was compounded by its marketing campaign, which especially emphasized its special attributes of sustainability, low fossil fuel usage, humane treatment, no on-farm chemicals, and health benefits. These valueadded traits were realized through their grass finishing process, which most consumers did not understand. For capital, the cooperative initially took a "do-ityourself" approach to avoid debt.

\section{Challenges of Scale: Tallgrass Prairie Producers Co-op}

Many studies show that consumers are hypothetically willing to pay premium prices for value-added traits (McCluskey, Wahl, Li, \& Wandschneider, 2005), but clearly there is a difference between hypothetical willingness to pay and actually paying. The Tallgrass Prairie Producers Co-op (Tallgrass) was started in 1995 and continued until it was liquidated in 2000 due to unprofitability (Wilson, 2001). The cooperative was originally formed to produce beef that was raised with sustainable values such as the conservation of natural resources, humane treatment of animals, no use of farm chemicals, and low use of fossil fuels.

However, the cooperative was never able to reach profitability and only survived based on the substantial subsidization provided by cooperative members' free labor. According to Wilson's analysis of Tallgrass, the fundamentals of developing a successful meat business based on social values were professional management of the business, sufficient volume to reach the break-even point, cost-effective operations, and realistic product pricing. These four aspects also had to be coupled with "a critical mass of supply and capital" (Wilson, 2001, p. 4). In order to reach the break-even point,
However, in the end, it did not have the capital needed to hire the skilled meat-industry professionals who could have identified and helped it capitalize on early market opportunities (Wilson, 2001).

Overall, Tallgrass was never able to develop the steady product flows and volume to make such investment in its business feasible. Barriers, or as Wilson stated, the "Catch-22," in its business were the competing problems at each stage of its value only produce finished beef during the spring, summer, and fall months because of their grass finishing process. Tallgrass co-operators also overestimated consumers' understanding of their process, social values, and willingness to pay a premium for these attributes. Wilson explains that reaching needed production volumes would have been a disaster because they could never have fulfilled such demand (2001). Second, finding a processing facility to process the beef at the costs needed to be profitable was also impossible. Large processing facilities need sufficient volume or are unwilling to deal with smaller producers. Furthermore, sufficient volume is needed to build distributor business. In the end, Tallgrass found itself with a low-volume, high-transaction-cost producchain (2001). First, in actual production they could 
tion and distribution process that left them unable to provide consistent supply throughout the year. Tallgrass created a business that needed volume to survive but was never able to properly balance scale and marketing management expertise with value-added traits and end consumer relationship attributes to actually attain the volume it needed.

Tallgrass relied heavily on the attribute of value-added traits for its model. It also emphasized the attribute of end-customer relationship. However, it did not expend enough energy to determine the correct the scale attribute, which led to problems with the attribute of value system coordination. This is depicted in figure 2 . This ultimately led to the cooperative's failure.

\section{From Commodity to Shinrai: Country Natural Beef}

First started in 1987 in response to low beef prices, Country Natural Beef (CNB) is a successful cooperative that has developed what Dan Campbell, editor of the USDA publication Rural Cooperatives, calls the "third way" of cooperative management (Campbell, 2006). One of the first things to note about the $\mathrm{CNB}$ cooperative is that it has almost no overhead and there are no equity positions for members. Capital requirements are raised from revenue derived from cattle sales. The cooperative owns no processing plants or feedlots, has no headquarters, and hires no employees. Management functions are taken care of by "internal partners" who hire their own people to perform the functions that require expertise (Stevenson, 2009). The costs of these functions are paid to the individual rancher or "internal partner," but these individuals are not on the official cooperative payroll. Feedlot functions are managed by cooperative members, but also are not owned by the cooperative itself. Illustrative of CNB's success is its growth from an organization slaughtering 3,000 head of beef per year in 1990, to an organization that slaughters 47,000 head of beef today (Bradbury, 2009).

This model is different from USPB. One model for cooperatives looking to return more dollars to producers is to pursue greater vertical integration. USPB is a prime example of this; it looked for controlling interests in processing facilities upstream in the value system in order to capture more of the food dollar. What CNB did was counterintuitive to classic cooperative expansion. One general problem in agricultural industries is the increasing level of capital needed to be competitive. This is exhibited by USPB's need to gain a majority stake in Farmland National. CNB has been able to avoid this due to its limited capital structure as it builds resiliency into the system. Activity in cattle commodity markets usually means that beef producers are vulnerable to volatile market prices that change weekly. A typical grainfed beef takes 18-20 months to get to slaughter weight. When a producer calves, he or she has no idea what price will be received when the animal is at market weight. As the logistics manager for CNB said, "We're in the beef business, not the cattle business" (Stevenson, 2009). A cattle business is only looking to deliver cattle and is not connected to the feedlot, processing facilities, distributors, retailers, or consumers. Being in the beef business means partnering with each stage on the value system to create situations with mutual reward or shinrai. CNB's first major customer, a 
Japanese beef company, introduced the cooperators to the concept of shinrai, which is the Japanese concept of mutual reward and mutual gain. CNB cultivates these relationships and also maintains direct contact with customers at retail establishments. Each CNB member is required to visit retail establishments three times a year to build relationships with both consumers and groundlevel employees of retailers. An example of cultivating close relationships is highlighted in the following story regarding CNB's relationship to its processor, AB Foods, as related by Dick Bradbury (2009), a founding member of CNB:

Several years back, our processor got into trouble and was forced to shut down for a few days until things could be smoothed over. During this time, they had a large order for the U.S. Army coming up. With the plant down and the timing of the order, AB [Foods] wasn't able to fill the order in time. We told $\mathrm{AB}$ they could use our beef that they had on hand at the lower price they needed in order to fill the order. They couldn't believe it. We worked it out with them that our cattle would be the first ones processed after they came back online. They filled their order and our customers didn't experience so much as a hiccup.

For CNB, AB Foods' innovative expertise helped to manage carcass utilization, an extremely important aspect of beef marketing. It also gave $\mathrm{CNB}$ the ability to track point of origin through its processes. The willingness to sell excess CNB product through its commodity channels has made $\mathrm{AB}$ Foods a tightly knit and noninterchangeable partner with CNB.

This partnership also goes into CNB's supply forecasting. It communicates with both its secondary processor (Fulton Meats) and its major retail partners. This communication allows its value chain to match supply with demand. Because demand is forecasted 18 months out, ranchers with CNB don't produce calves that don't have buyers. This, in essence, establishes a system that comes close to pull production for $\mathrm{CNB}$. It is not producing as much beef as possible and selling it on the spot market. It is adding intentionality to its production based on its own and its partner's expectations of demand. As Dick Bradbury says, "Every animal I produce is already sold" (2009). It should be noted that achieving true pull production in beef may be difficult given the difference between end customer lead time and production lead time.

This more pull-like method of production represents a departure from other commodity beef production and processing models. CNB is concentrating both on maintaining sufficient scale and maintaining involvement in every stage of the value-added process, which allows it to eliminate waste from overproduction. Additionally, $\mathrm{CNB}$ has been able to combine low capital expenditure with profitability. Low overhead means that difficult economic conditions and lowered demand for CNB products can lead to adjusted production targets. CNB is able to cut down on production and is not required to maintain fixed production targets or face losses. Cuts are determined by the cooperative, but farms can move beef through other channels when $\mathrm{CNB}$ demand decreases. The shinrai philosophy can be tested when the cooperative loses customers. However, the low-capital nature of the cooperative allows it the flexibility to survive difficult periods.

Though CNB uses sustainable production methods, it is not certified organic. CNB beef carcasses have attributes that include grass-fed, with only short times on the feedlot (short fed), antibiotic free, and humanely raised. Though its story clearly includes environmentally friendly concepts, it has not overemphasized this attribute of its model.

While these methods have worked well for CNB, they do come with disadvantages, risks, and assumptions. First, one of CNB's major customers, accounting for $60 \%$ of sales, is Whole Foods Market (Campbell, 2006). The relationship with Whole Foods Market has grown from a handshake agreement to formal contracts. There is significant overlap in CNB's business model (story) and Whole Foods Market's customer base (Stevenson, 
2009). However, with one customer taking $60 \%$ of the production, there is a risk to $\mathrm{CNB}$ that Whole Foods business would have a disproportionately negative effect on CNB business. This actually happened when Whole Foods changed from a regional to a centralized buying structure. This hurt the regional relationships that had already been cultivated and maintained over a long period of time. CNB production was set up to deliver beef to Whole Foods operations west of the Rocky Mountains. At the time of the changeover, Whole Foods had been growing rapidly and was looking for beef suppliers that would be able to deliver product to their locations nationally. Eventually, the relationship was repaired, but this does highlight risks associated with dependence on one large customer.

Furthermore, Whole Foods is able to connect $\mathrm{CNB}$ with consumers who are willing to pay more for direct contact with producers, environmental stewardship, social values, and antibiotic- and hormone-free production methods. There are a limited number of retailers similar to Whole Foods in the market. It might not be possible for every producer to connect with a retail and distribution system that has access to such markets. Additionally, pull systems of production require high amounts of coordination with customers and processors. CNB must pay for its managing members' and their employees' time to cultivate these relationships. This has proved profitable for CNB because of its access to premium markets. It might not be profitable for organizations without access to premium markets to take on increased transaction costs.

CNB's model includes achieving the proper scale, not just size for the sake of size. It uses a pull system of production that is facilitated by good value system coordination. This coordination is likely one outcome of the customer relationships that CNB has established. It has an innovative way of ensuring the attribute of marketing management expertise. Finally, its value-added traits are not more than what the market is willing to buy.

Figure 3 represents the relative balance that $\mathrm{CNB}$ has struck in accessing volume markets for their

Figure 3. Country Natural Beef Model

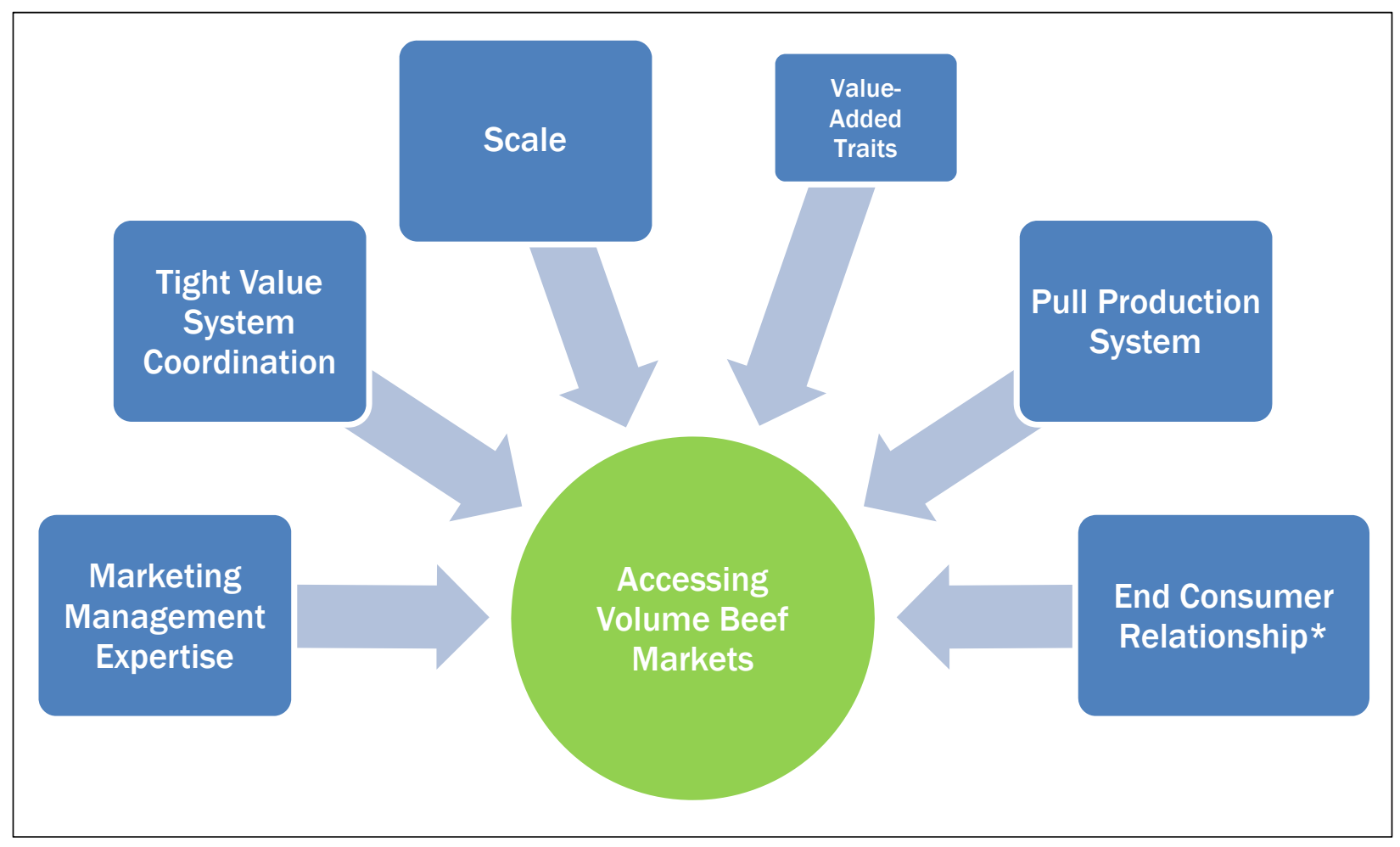


small producers. We have placed an asterisk next to end-customer relationship as a way to highlight the fact that a significant portion of their sales comes from one customer, making CNB very dependent on that customer.

\section{Discussion: Toward a New Model}

These three case studies were chosen because of the different model each represented. Organizations using similar models might achieve different results than the firms presented here. However, the three case studies do give an indication as to the key attributes to consider when evaluating a cooperative model for smaller producers to access volume markets: marketing management expertise; value system coordination; scale; value-added attributes; production system design; and endcustomer relationship. Table 1 is a summary of the three case studies. For each, the authors offer an admittedly subjective rating on each attribute. It is consumer relationships that are vital in success. However, as tempting as a formula for beef marketing success might be, it is more important to recognize the highly dynamic nature of these attributes. Depending on the scale, different levels of value-added traits, expertise, relationships across the value system, or direct consumer contact will be needed. For example, as consumer contact increases, more marketing opportunities are possible with less scale due the more direct connections between consumer and producer. The discussion below will note where such interactions are particularly important.

Both USPB and CNB represent, to date, successful cooperative enterprises that have been able to connect small producers to volume markets. Yet USPB slaughters slightly more than eight times the beef that $\mathrm{CNB}$ does. As Dick Bradbury from $\mathrm{CNB}$ has stated, "We aren't even a drop in the bucket of the beef market" (2009). On the other hand, Tallgrass was never able to reach the scale needed to access volume markets and attain profitability. Scale, it seems, at least to a certain point, is important. A small producer might be able to sell 100-200 head of beef directly to consumers. However, as the number of beef marketed increases, small producers often have insufficient scale to hire a marketing manager full time, yet cannot market enough beef part time to enter into volume markets. Scale must thus be considered a "Catch-22" attribute.

Marketing management expertise is clearly an important attribute for beef producers looking to market their products into retail markets. As Mike Lorentz said, "Don't be naive enough to think that you can part-time people out of a fulltime job.

These people wake up in the morning and all they think about is selling more meat" (2009).

Tallgrass's negative experience in niche markets is partially due to its failure to hire the required expertise. Market opportunities that "do-it-your-

Table 1. Summary of Case Studies of Cooperative Business Models for Beef Marketing

\begin{tabular}{l|c|c|c}
\hline Attribute & U.S. Premium Beef & $\begin{array}{c}\text { Tallgrass Prairie } \\
\text { Producers Co-op }\end{array}$ & Country Natural Beef \\
\hline $\begin{array}{l}\text { Marketing Management } \\
\text { Expertise }\end{array}$ & $\begin{array}{c}\text { Professional, full-time } \\
\text { management }\end{array}$ & Not significant & $\begin{array}{c}\text { Internal partners hire } \\
\text { expertise as needed }\end{array}$ \\
\hline Value System Coordination & $\begin{array}{c}\text { Emphasis on } \\
\text { communication between } \\
\text { value chain stages }\end{array}$ & $\begin{array}{c}\text { Poor due to seasonal } \\
\text { production }\end{array}$ & Shared Risk and Rewards \\
\hline Scale & $\begin{array}{c}\text { Sufficient to secure } \\
\text { processing capacity }\end{array}$ & $\begin{array}{c}\text { Unable to maintain } \\
\text { proper scale }\end{array}$ & $\begin{array}{c}\text { Proper, in part due to } \\
\text { pull production }\end{array}$ \\
\hline Value-Added Traits & Lower priority & Primary attribute & $\begin{array}{c}\text { Appropriate to what } \\
\text { market will bear }\end{array}$ \\
\hline Production System & Push system & Push system & Pull system \\
\hline End-Customer Relationship & Not emphasized & Significant attribute & Customer visits required \\
\hline
\end{tabular}


self" ranchers may have missed could have been caught by more experienced professionals. In contrast, USPB and CNB both hired the necessary expertise. USPB has an official management team, while individual ranchers with $\mathrm{CNB}$ either use their own expertise or hire expertise on a contract basis.

The case studies make clear that the issue of scale and expertise are linked. Consider the rule of thumb regarding scale from an industry presentation by Mike Lorentz of Lorentz Meats. When considering hiring a beef marketing expert, he suggests that it will take at least 1,000 head of beef to enter into volume retail and distribution markets (Lorentz, 2009). The reasoning behind this statement is that accessing volume markets takes at least one full-time marketing and sales employee. In order to pay a skilled full-time employee, a roughly 1,000 -beef minimum is necessary. For direct marketing at low volumes, an additional employee is not needed. Between 200 beef and 1,000 beef is a no man's land that requires more marketing labor than one person can give, but also does not generate enough profit to justify hiring.

Value-added traits such as U.S. raised, humanely raised, antibiotic-free, GMO-free, and grass-fed are all important for accessing premium prices and volume markets. The natural meat and poultry market saw a $77 \%$ growth in market share between 2002 and 2003, and was a significant part of the organic food industry (Organic Trade Association, 2004). McEachern and Schröder (2004) found that a significant proportion of respondents to their survey $(76 \%)$ would prefer to buy fresh meat products with social values-based labeling. Thus, there is a market for food and fiber products that convey a message of value-added traits (range-fed, humanely raised, etc.) to consumers that go beyond organic standards.

Value-added traits can help small producers and cooperatives succeed, but they cannot make a beef business. These attributes have helped CNB to be successful. However, the experience with $\mathrm{CNB}$ can be contrasted with USPB, which does not seek to compete in the beef market based on sustainable values and attributes, yet still has helped small beef producers be successful in volume markets. The experience of Tallgrass indicates that even though social values and health aspects might be important, there is a limit on what consumers are willing to pay for these aspects. Tallgrass received recognition in sustainable agriculture circles from people who wanted to believe that its environmental stewardship, social values, and health benefits were ushering in a new age for small agricultural producers. However, its lack of profitability shows that while markets based on value-added traits might be growing, they still must balance other factors in their business. The key to the value-added traits attribute is thus selecting a level of value-added traits that will sell in sufficient quantity and price to maintain profitability. The three cases studied here show three different approaches with regard to this attribute.

Coordination across the value system is also important. However, there are several different methods to achieving these goals. There are, as CNB has shown, shinrai methods of mutual risk and reward that require less capital outlay, but more regular maintenance of the relationship. Across each stage of the value chain, CNB maintains close relationships with companies that have similar goals and business strategies. On the other hand, USPB decided that it would invest downstream in processing capacity in its attempt to more tightly orchestrate its supply chains. A major focus of its business is greater coordination of production, not supply chain relationships. CNB appears to focus on the "soft side" issues, while USPB appears more focused on the technical side.

CNB has also been able to successfully partner across its value chain to better match its production to demand, thus eliminating waste. It has created a pull system that is unique. Most organizations, USPB included, are still tied to facilities that require a certain level of utilization and are required to push product out into the market, creating overproduction during times of limited demand. Vertical integration has helped to manage this better, but large processing facilities still must process sufficient product to reap economies of scale. In many ways, USPB doesn't have a lot of 
flexibility in its production numbers because of the driving need to keep consolidated production facilities operating. These cases point out how system coordination and system of production are linked. Simply put, greater coordination allows the opportunity to take advantage of the benefits of pull production systems.

The final attribute considered is relationships with end consumers. This can also be an important factor or a difficult burden when coordinating across the value system. Tallgrass, for example, was only able to market its beef to high-transactioncost, small and independent retailers. Although it had high degrees of direct contact with consumers, these high transaction costs were a barrier to profitability. On the other hand, CNB employs farmer visits to retail establishments and restaurants that serve its beef, which has been a key to promoting customer loyalty, connection with the farmer or rancher, and overall success. USPB does not have a direct relationship with the end consumer, but has sufficient scale to compete effectively in commodity beef sectors. The case studies all point to the idea that strong relationships with end customers facilitate system coordination and pull production systems.

\section{Conclusion}

The ability of small producers working alone to develop and access volume markets is limited. Direct marketing of products is not feasible in high-volume environments, as it is difficult for one small producer to manage both marketing and production aspects at sufficient volumes to be useful for an increasingly consolidated retail sector. Because of this, cooperative enterprise has long been an option for small beef producers to access volume markets and increase market power. Cooperatives that represent small producers must balance several factors to be successful selling into retail markets, as represented in figure 4 .

The aforementioned qualities must be considered by small beef producers. It is also important to note that these qualities are dynamic parts of the whole business. Stronger relationships with end consumers might negate the need for different value-added traits or going to a larger scale. The degree to which each cooperative fulfills these factors is often a moving target based on the particular situation of a business. It would be beneficial for small beef producers to learn from the experiences of Tallgrass, Country Natural Beef, and U.S. Premium Beef, and also understand that there

Figure 4. A New Model for Small Producers

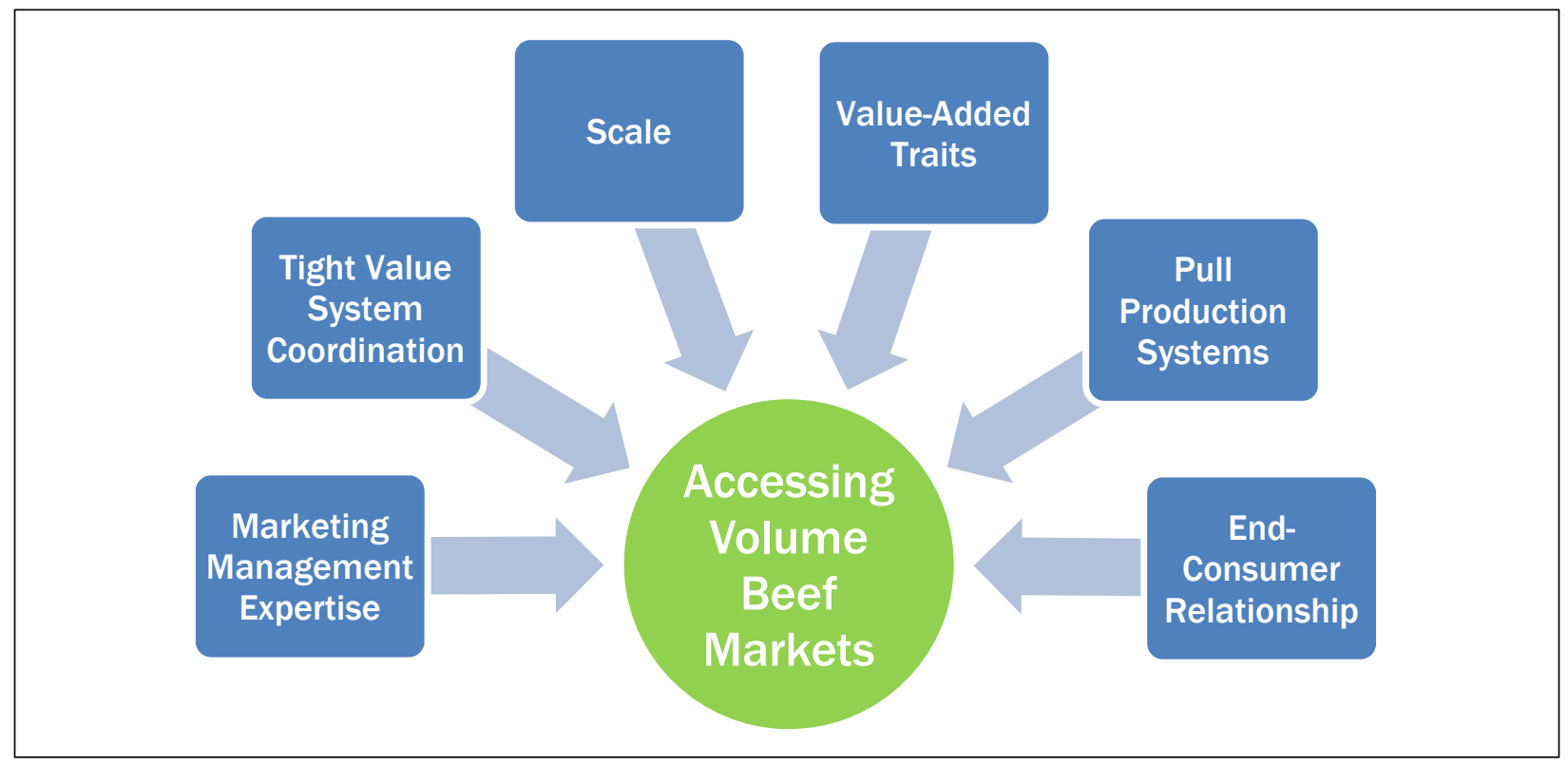


is no one way to beef marketing success. Finding the sweet spot for each factor is more an art than a science.

This research has synthesized three case studies and outlined some of the factors of success in beef marketing. Based on this, future research on small producer success in volume markets should include the following.

1. Additional factors responsible for small producer success in volume markets.

2. Research that highlights success factors in volume beef marketing using empirical methods.

3. Research that highlights how pull methods of agricultural production can be better incorporated into volume beef-marketing schemes.

4. Research that further investigates how different factors responsible for small producer success in volume beef markets interact with each other.

Research that extends the current paper along these lines is likely to give important practical guidance to small producers.

\section{References}

Anderson, J. D., \& Hudson, D. (2008, September). Acquisitions and integration in the beef industry.

Policy Issues, 2, 1-4. Available at

http://www.choicesmagazine.org/magazine/ pdf/PI2.pdf

Barkema, A., Drabenstott, M., \& Novack, N. (2001). The new U.S. meat industry. Economic Review, QII, 33-56. Available at http://EconPapers.repec.org/ RePEc:fip:fedker:y:2001:i:qii:p:33-56:n:v.86no.2

Born, H. (2001). Keys to success in value-added agriculture [Report no. IP172]. National Center for Appropriate Technology. Retrieved from the National Sustainable Agriculture Information Service website: http://www.attra.org/attrapub/keystosuccess.html
Bradbury, D. (2009, July 22). Values based value chains. Keynote address at the Communities of Practice Workshop, Des Moines, Iowa.

Campbell, D., (2006). The natural. Rural Cooperatives, 73(4), 4-9. Retrieved from USDA Rural

Development website: http://www.rurdev.usda. gov/rbs/pub/jul06/natural.htm

Cousins, P. D., Handfield, R. B., Lawson, B., \& Petersen, K. J. (2006). Creating supply chain relational capital: The impact of formal and informal socialization processes. Journal of Operations Management, 24(6), 851-863. http://dx.doi.org/10.1016/j.jom.2005.08.007

Das, K. (2009). Relationship marketing research (19942006): An academic literature review and classification. Marketing Intelligence \& Planning, 27(3), 326-363. http://dx.doi.org/10.1108/02634500910955236

Dimra, E., \& Skuras, D. (2003). Consumer evaluations of product certification, geographic association and traceability in Greece. European Journal of Marketing, 37(5/6), 690-705. http://dx.doi.org/10.1108/03090560310465099

Franks, J. (2003). Current issues in marketing organic milk in the UK. British Food Journal, 105(6), 350363. http://dx.doi.org/10.1108/00070700310481711

Holweg, M., \& Pil, F. K. (2008). Theoretical perspectives on the coordination of supply chains. Journal of Operations Management, 26(3), 389-406. http://dx.doi.org/10.1016/j.jom.2007.08.003

Katz, J., \& Boland, M. (2000). A new value-added strategy for the U.S. beef industry: The case of U.S. Premium Beef Ltd. Supply Chain Management: An International Journal, 5(2), 99-110. http://dx.doi.org/10.1108/13598540010320018

Kim, H.-S., \& Kim, Y.-G. (2009). A CRM performance measurement framework: Its development process and application. Industrial Marketing Management, 38(4), 477-489. http://dx.doi.org/10.1016/ j.indmarman.2008.04.008

Krajewski, L. J., \& Ritzman, L. P. (2002). Operations management: Strategy and analysis (Sixth edition). Upper Saddle River, New Jersey: Pearson Education. 
Lau, M., Beverly, M. M., Kelley, S. F., \& Hanagriff, R. D. (2007). The economic and social values consumers place on all natural/healthy beef products and how this value added commodity effects demand: A literature review. The Business Review, Cambridge, 9(1), 159-164.

Leopold Center. (n.d.). Marketing \& Food Systems Initiative. Retrieved May 9, 2011, from http://www.leopold.iastate.edu/research/ marketing.htm

Lorentz, M. (2009, July 22). Making sense of meat marketing. Presentation to meeting of the Iowa Grass Based Livestock Working Group, Des Moines, Iowa.

McCluskey, J. J., Wahl, T., Li, Q., \& Wandschneider, P. R. (2005). U.S. grass-fed beef: Marketing health benefits. Journal of Food Distribution Research, 36(3), 1-8. Available through AgEcon Search at http://purl.umn.edu/27758

McEachern, M. G., \& Schröder, M. J. A. (2004). Integrating the voice of the consumer within the value chain: A focus on value-based labeling communications in the fresh-meat sector. Journal of Consumer Marketing, 21(7), 497-509. http://dx.doi.org/10.1108/07363760410568716

Nitschke, T., \& O’Keefe, M. (1997). Managing the linkage with primary producers: Experiences in the Australian grain industry. Supply Chain Management: An International Journal, 2(1), 4-6. http://dx.doi.org/10.1108/13598549710156295

Ollinger, M., Nguyen, S., Blayney, D., Chambers, B., \& Nelson, K. (2005). Structural change in the meat, poultry, dairy, and grain processing industries (Economic Research Report No. 3). Washington, D.C.: U.S. Department of Agriculture Economic Research Service. Retrieved from http:/ /www.ers.usda.gov/ publications/err3/err3.pdf

Organic Trade Association. (2004). The OTA 2004 Manufacturer Survey overview. Greenfield, Massachusetts: Author. Retrieved from http://www.ota. com/pics/documents/2004SurveyOverview.pdf

Porter, M. (1985). Competitive advantage: Creating and sustaining superior performance. New York: The Free Press.

Sexton, R. (2000). Industrialization and consolidation in the U.S. food sector: Implications for competition and welfare. American Journal of Agricultural Economics, 82(5), 1087-1104. http://dx.doi.org/10.1111/0002$\underline{9092.00106}$
Stank, T., Crum, M., \& Arango, M. (1999). Benefits of interfirm coordination in food industry supply chains. Journal of Business Logistics, 20(2), 21-40.

Stevenson, S. (2009). V alues-based food supply chains: Country Natural Beef [Case study]. Madison, Wisconsin: Center for Integrated Agricultural Systems. Retrieved from http://www.agofthe middle.org/pubs/cnbcasestudyrev012711.pdf

U.S. Department of Agriculture. (2005). Agricultural concentration [Farm Bill Forum Comment Summary \& Background document]. Retrieved March 16, 2010, from http://www.usda.gov/documents/ Agricultural Concentrationd.doc

U.S. Department of Justice. (2009). The HerfindahlHirschman Index. Retrieved March 16, 2010, from http://www.justice.gov/atr/public/testimony/ hhi.htm

U.S. Premium Beef, LLC [USPB]. (2009). U.S. Premium Beef LLC Announces Record Cash Distribution [Press release].

USPB. (2011a). U.S. Premium Beef History. Retrieved June 8, 2011, from

http://www.uspremiumbeef.com/History.aspx

USPB. (2011b). Welcome. Retrieved June 9, 2011, from http://www.uspremiumbeef.com/Home.aspx

van Bekkum, O. (2001). Cooperative models and farm policy reform: Exploring patterns in structure-strategy matches of dairy cooperatives in protected vs. liberalized markets. Assen, The Netherlands: Koninklijke Van Gorcum.

Weaver, R. D. (2008). Collaborative pull innovation: Origins and adoption in the new economy.

Agribusiness, 24(3): 388-402. http://dx.doi.org/10.1002/agr.20165

Wilke, J. R., \& Etter, L. (2008, October 21). U.S. News: Brazilian Beef Purchase Is Challenged by the U.S. Wall Street Journal, p. A6.

Wilson, A. (2001, October). Romance vs. reality: Hard lessons learned in a grass-fed beef marketing cooperative [Kansas Rural Center's Rural Papers Report MG6E.1]. Retrieved from http://www.kansas ruralcenter.org/publications/RomancevsReality.pdf

Zippay, A. (2008, October 30). Fed files anti-trust lawsuit to block beef merger. Farm and Dairy. Retrieved from http://www.farmand dairy.com/news/fed-files-anti-trust-lawsuit-toblock-beef-merger/10409.html 
Journal of Agriculture, Food Systems, and Community Development ISSN: 2152-0801 online www.AgDevJournal.com 